\title{
Does Market Competition Encourage Strategic Action in the Private Education Sector? ${ }^{1}$
}

\author{
JANICE AURINI \\ LINDA QUIRKE
}

\begin{abstract}
According to the market hypothesis, market forces encourage schooling organizations to strategically outsmart their competition in ways that improve the quality of teaching and learning. Based on eighty interviews with private education owners or managers in Toronto, Ontario, we find little evidence that entrepreneurs respond to competition in the way that the theory predicts. Market competition does not inform how entrepreneurs understand their role in the wider education sector or how they make sense of their actions. Instead, entrepreneurs tie their program, hiring, and customer service decisions to an ideological commitment to students, defining themselves as educators. Our data suggest that this perception guides their actions more than market forces. This paper opens the black box of private education organizations, and offers a nuanced addition to mounting research that challenges the connection between market competition and school performance.
\end{abstract}

Key words: market hypothesis, market competition, private education, private schools, tutoring, school choice

Résumé. Selon l'hypothèse de marché, les forces du marché encouragent les institutions de scolarisation de se montrer plus futé que leur compétition des façons qui améliorent la qualité d'enseignement et d'apprentissage. Fondé sur 80 interviews avec des propriétaires ou directeurs d'éducation privée de Toronto (Ontario), nous trouvons peu de preuves que les entrepreneurs réagissent à la compétition d'une manière que la théorie prévoit. La compétition de marché n'indique pas comment les entrepreneurs comprennent leur rôle dans le vaste secteur d'éducation ni comment ils comprennent leurs actes. Plutôt, les entrepreneurs associent leurs décisions de programme, d'embauche et de service clientèle à un engagement idéologique aux élèves et en se définissant comme éduca-

1. Acknowledgements: The authors would like to thank Scott Davies, Kevin Haggerty, and the anonymous reviewers for their helpful comments and suggestions. Data collection for this project was generously supported by a SSHRC doctoral fellowship (20042006).

(C) Canadian Journal of Sociology/Cahiers canadiens de sociologie 36(2) 2011 
teurs. Nos données suggèrent que cette perception guide leurs actions plus que les forces du marché. Cet article ouvre la boîte noire des organismes d'éducation privée et offre une addition subtile à la recherche croissante qui débat le rapport entre la compétition de marché et les performances scolaires.

Mots clés: Hypothèse de marché, compétition de marché, éducation privée, écoles privées,

If we first implement choice, true choice among public schools, we unlock the values of competition in the educational marketplace. Schools that compete for students, teachers, and dollars will, by virtue of the environment, make those changes that allow them to succeed . National Governors' Association (1991:84)

\section{INTRODUCTION}

For decades academics and policy makers have debated the merits of competitive and noncompetitive environments with respect to organizational performance. In theory, organizations in the marketplace must accurately devise strategies to combat competition in ways that mutually benefit their clients and their bottom line. To survive, organizations must be highly attuned and responsive to not only customer demands but also to the goods and services of their competitors. Market advocates claim that the imperative to attract clients and navigate through uncertain market conditions encourages higher quality goods and services, and weeds out inefficient organizations. Accordingly, organizations will theoretically gather information about their competitors, and respond by creating high quality, innovative products and effective customer service protocols. The "market hypothesis" has been used to justify the privatization of formally state run sectors such as energy, sanitation, communication, and transportation (Maranto et al. 2001; Megginson and Netter 2001).

The market hypothesis has been extended to education organizations and assumes that public schools' noncompetitive and monopoly status lacks the "requisites of effective performance" (Chubb and Moe 1990:67). An intricate web of unions, teachers, and administrators are seen to wrap schools in a protective blanket of bureaucracy. In theory, if schools are treated as individual, autonomous agents that compete for resources, enrolments, and reputations, they should cater to their local communities in ways that directly benefit students. In a process we dub "strategic action" these calculated responses include raising academic achievement, creating innovative pedagogical approaches, improving teaching and learning, and responding to student or parental demands. 
Over time, market environments are theorized to improve the education system by driving out inefficient and unresponsive schooling organizations (for a review see Belfield and Levin, 2009; see also Chubb and Moe 1990; Lieberman 1993; Friedman 1962; Maranto et al. 2001; Peterson and Campbell 2001; Ouchi 2003; Wilson 2006; see also Davies et al. 2006; Davies and Quirke 2005). The introduction of charter schools, magnet schools, vouchers, and the full or partial funding of private schools in parts of the United States and Canada have been introduced in part to generate competition between schooling organizations and expand school choice options for parents (e.g., Holmes, 2008; Witte, 2000).

Does competition encourage strategic action in the way that the market hypothesis predicts? Despite the popularity of the market hypothesis among academics (for a discussion of Canadian examples see Bosetti 1998, Bosetti and Pyryt 2007; Dooley and Payne 2007; Holmes 2008; Robson and Hepburn 2010) and policy makers (for Canadian examples see C.D. Howe Institute; Fraser Institute), few studies concretely examine the connection between schooling organizations and competitive forces at the micro level. Instead, the prime strategy has been to infer the benefits of competitive processes based on large-scale quantitative data. While this valuable literature has examined student achievement, program innovations and teacher or parent satisfaction in quasi-market environments (see Belfield and Levin 2002; 2009), we have been unable to find research that directly examines how entrepreneurs interpret and respond to market competition or whether competition is the lever that drives best practices at the micro level.

Our paper adds to this literature by examining whether market competition informs how private education entrepreneurs understand their role in the wider schooling environment. Do private education entrepreneurs recognize the competitive environment? If so, does the competitive environment inspire best practices? To analyze this process we draw on eighty interviews with owners or representatives from 3 forms of private education in Toronto, Ontario: independent tutoring businesses, learning centre franchises, and private schools. As we describe below, these schooling organizations have all the ingredients central to market effects including direct funding by clients, survival based solely on clients' willingness to pay, and low formal regulation (Merrifield 2008). These qualities provide a unique opportunity to examine how competitive forces shape organizational directives at the micro level and whether competition is the engine that drives entrepreneurs to improve the content and delivery of their services. 


\section{The Market Hypothesis and Education Reform}

Traditionally, public schools are theorized to privilege external legitimacy over internal efficiency or goals (Meyer and Rowan 1978; Weick 1976). Critics argue that public schools' highly bureaucratized form makes them unresponsive to their clients, and limits innovative pedagogical approaches (Chubb and Moe 1988; Friedman 1962; for a discussion see Lubienski 2003). Public schools are seen to channel their resources into the reproduction of practices that serve the interests of bureaucrats and teachers rather than their clients. Resource scarcity for clients, reputations, and supplies are theorized to encourage the crème of the education sector to rise. When schools compete for funding or clients, they can no longer take fee-paying parents or students for granted and must respond through continual program improvements, ensuring that their programs and services are consistent with the needs and preferences of families (Belfield and Levin 2005). In theory, market competition refocuses schools' attention outward, toward their consumers (Lubienski 2005).

As the incentive structure shifts, from one based on monopolies to one based on open competition, schooling organizations are theorized to "re-couple" their institutional activities with outcomes or risk declining enrolments and, ultimately, failure. Customers, needing to judge differences in school quality, scrutinize performance benchmarks such as standardized test results, university placement, and graduation rates. Savvy consumers are assumed to use these indicators to shop around for superior programs that deliver high quality services. This incentive structure, according to the market hypothesis, ultimately improves student achievement as parents "vote with their feet" and exit underperforming schools. As Chubb and Moe (1988:1068) summarize:

In the private marketplace ... if parents and students do not like the services they are being provided, they can exit and find a school whose offerings are more congruent with their needs ... schools that fail to satisfy a sufficiently large clientele will be weeded out.

The market hypothesis tradition is built on the implicit assumption that providers are highly sensitive to the competitive environment, and make a concerted effort to mitigate its impact. Yet the process of how macro-level competitive pressures are engaged, ignored, or misunderstood by frontline actors has been largely overlooked. If market competition encourages strategic action we should witness two interconnected behaviours. First, entrepreneurs should recognize competitive forces such as a competitor opening up across the street, and believe that competitive force is somehow important or consequential. Second, entrepre- 
neurs should directly link these competitive forces with a strategic action, such as hiring the best teachers or improving their program. In short, competitive forces should (even minimally) inspire owners or managers to make changes that improve the content and delivery of their services.

In this tradition, we ask: Do entrepreneurs recognize competitive pressures emanating from the environment? If so, does market competition drive strategic actions in ways that improve the quality of education organizations? To answer these questions we examine how macrolevel market forces are "pulled down" to the micro level and translated into everyday action. First, if market competition improves academic achievement, the market hypothesis predicts that our interviewees have basic information about their competitors such as their academic performance, graduation rates, test score, grade improvements, or other standard markers of academic excellence. The theory assumes that this awareness should encourage our interviewees to improve their own pedagogical approaches, hire the best and the brightest teachers (and also fire underperforming teachers), and retool their teaching methods.

Second, the market hypothesis assumes that our interviewees have at least a basic understanding of their competitors' products and services. Accordingly, we expect to hear our interviewees discuss not only creating exciting and novel approaches to teaching and learning, but also how these responses are at least partly inspired by competitive pressures. Finally, at the micro level, the market hypothesis assumes that strategic actions include developing a strong customer service ethos as interviewees attempt to outshine their competitors and build positive connections with parents and students. To be clear, we anticipate that our interviewees' understandings and actions are informed by a complex mixture of personal biography, history, knowledge, and skills, but argue that if market forces inspire positive change "competition" should at least be part of their deliberation process.

Through an in-depth study of the frontline actors in the private education sector, this paper contributes to understandings of how market forces are understood by private educators, the way in which these forces inform their everyday business decisions, and whether market competition inspires better quality educational goods and services.

\section{Situating our Study within the Context of Private Education RESEARCH}

In examining how educational organizations operate under market conditions, researchers have looked to schools of choice. Current school choice research focuses on schooling organizations that enjoy endowments, 
government funding or access to church subsidies, including religious schools, charter schools, magnet schools, and voucher programs (Henig 1999). However, key market conditions that are almost entirely absent from current school choice research include: direct payment by parents, price and survival based solely on parents' willingness to pay, and low formal regulation to allow easy market entry and schooling differentiation (see Merrifield 2008). Consequently, Merrifield (2008:1) observes that "researchers have drawn conclusions about apples by studying lemons."

The independent tutoring businesses, learning centres, and private schools in this paper allow us to examine how entrepreneurs negotiate competitive pressures emanating from the environment. These businesses do not receive state or other sources of funding, making revenue generation a constant concern. Consumers can enter and exit their services easily, and the businesses do not benefit from truancy laws or catchment areas to provide a captive audience for their services. Instead their financial survival is based solely on their ability to attract new students and maintain a stable client base (Aurini 2004; Davies and Quirke 2005).

Prices and programs also vary, allowing consumers to select from a range of programs and price points. Learning centres, for example, charge $\$ 75$ to $\$ 400$ per month, and offer products that range from small to large group instruction, whole language to phonics programs, online or audio taped programs to face-to-face instruction and so forth. Similarly, what we term "third sector" schools are characterized by a particular philosophy or curricular focus, allowing customers to choose from a wide range of programs such as the arts, the environment, ancient languages, music, or liberal arts (Davies and Quirke 2006; Quirke 2009).

The businesses we selected also are unencumbered by a strong regulatory environment. Unlike state-funded public schools or charter schools, there are few restrictions placed on the private education sector in Ontario. Private schools are free to operate without interference from the state and are only obligated to provide documentation that their premises have been inspected and approved by health, safety, and fire officials. Private schools must file an "intention to operate" document once a year with the Ontario Ministry of Education, and must offer instruction during regular school hours to at least five enrolled students. Accredited private schools that grant high school credits are required to use the provincial curriculum, and comply with yearly inspections. However our interviewees noted that inspectors allow them a great degree of latitude (Davies and Quirke 2006). Elementary third sector schools face even fewer regulations; they are not required to follow the provincial curriculum, and are not inspected by the state. Moreover, elementary and secondary private schools are not required to participate in prov- 
incial testing, nor are they required to fulfill a "charter" as in the case of charter schools. Tutoring businesses and learning centres face even fewer regulations and may use any curricular or teaching materials they deem appropriate.

Private schools, independents, and learning centres are also not required to hire certified teachers. Regardless of curricula or accreditation status, these businesses have complete discretion over hiring staff and other operational policies and procedures (see Quirke 2009; Davies et al. 2006). In general, private educators in Ontario are free to craft programs and hire teachers in direct response to consumer demand, and are accountable to their clientele, not to the government.

Beyond low levels of formal regulation, these businesses also operate in an environment that is increasingly competitive. Between 1996 and 2008, the number of Ontario private tutoring businesses and learning centre franchises almost doubled to just under 500 locations (Scott's Directories, 1996-2008). With one in ten children attending private schools, Toronto's rate of private school enrolment is significantly higher than the Canadian average of $5.3 \%$. The total number of private schools in Ontario has swelled from 500 to over 900 in the past two decades (Ministry of Education, 2011). ${ }^{2}$ Overall, the growth of private education businesses has occurred rather spontaneously as the Ontario government has done little to encourage private sector growth, having cancelled plans for innovations such as charter schools as well as a small tax credit for private school tuition or funding for private tutoring. These conditions stand in stark contrast to the United States where politicians have strongly pushed and funded charter schools and voucher programs (Witte 2000), and have funded private tutoring through initiatives such as No Child Left Behind (Zimmer et al. 2010).

\section{Data And Methods}

This paper draws on interviews with eighty private business owners and managers from three forms of private education: 1) independent tutoring businesses, 2) learning centre franchises and, 3) nonelite, secular ("third

2. Of the 45 schools in this sample, 3 ceased operations shortly after data were collected. Since then, 11 more third sector schools in our original sample have closed their doors. Of these 11 schools, one was stripped of accreditation by the state and could no longer grant high school credits. With such a small sample of private schools, we cannot generalize this "failure" rate beyond our sample. Yet, even after accounting for school closures, the net growth of private schools in Toronto remains strong (Davies and Quirke 2006). There is no official public registry of private tutoring businesses in Ontario that would allow us to accurately track closure rates. However, based on available data the number of independent and learning centre businesses has grown and outpaced demographic or business growth more generally (Aurini 2004; Aurini and Davies 2004). 
sector") private schools. Most interviews were conducted between 2001 and 2003; additional interviews were conducted in 2004 and 2005 as new businesses opened. We interviewed owners, managers, or principals from twenty-two independent tutoring businesses, thirteen learning centre franchises, and forty-five third sector schools in Toronto, Ontario. This design permitted us to capture the heart of the for-profit education sector in a geographic region. As we outline below, we used a purposeful sampling technique, selecting subsectors of private education businesses that reside in a purer market setting.

To generate a sampling frame of tutoring businesses and learning centres, we relied on the Bell Yellow Pages telephone directory (East and West directories) dating back to the 1960s, to chart the growth of tutoring companies over several decades. We focused only on businesses that operate on a full-time basis, and offer educational services in core subject areas such as reading and math. We excluded programs that are offered by charities, religious organizations, and libraries. These limitations were intended to ensure a stable population of education organizations operating in a competitive marketplace. We then contacted all independent tutoring businesses that met these sampling criteria. While most independent tutoring businesses largely offer basic math and reading tutorials, learning centres are franchised operations that offer a wider variety of educational services such as study skills testing and preschool programs. Since learning centre franchises have standardized practices and programs, we interviewed the franchisers or national representatives of five major brands, then supplemented these interviews with interviews with local franchisees.

The sample of third sector schools was drawn from a government registry of Toronto private schools. Third sector schools were defined as: nonreligious schools that are neither Montessori, Waldorf, language, reform schools, nor listed on the elite independent registry. In Ontario, one fifth of private school students attend such third sector schools, many of which offer a focused, thematic "niche" pedagogical approach, rather than a comprehensive approach (Quirke 2009; Davies and Quirke 2007; 2005). We deliberately excluded elite and religious private schools to focus on schools that do not typically receive funding from endowments, powerful alumni, or religious communities. These alternative sources of funding buffer market effects, and would compromise our analysis. Following Henig's (1999) and Merrifield's (2008) guidelines, we also excluded both public and Catholic schools, as they are fully funded by the state, and are not subject to the principles of supply and demand. We interviewed key actors in the private education field - the head of a private school lobby group, educational consultants, representatives of 
the Canadian Franchise Association, and home-schooling organizations. The first author also conducted a participant observation study, tutoring in a learning centre franchise for one year.

\section{Data Collection and Analysis}

Interviews were usually held at the school or business and lasted 90-120 minutes. The interview schedule was semistructured, allowing subjects to elaborate on their experiences and share anecdotes. Interviews were tape recorded and transcribed with the permission of the interviewee. Pseudonyms are used to protect the confidentiality of participants.

The first portion of the interview was largely descriptive, ranging from the history of the business to the programs or services offered. Another portion of the interview tapped into our interviewees' perceptions of how their businesses fit into the larger environment of schooling, and how other organizations, including public schools and other businesses, affected their operations and everyday decision-making. These questions attempted to unpack how entrepreneurs understood and responded to competition processes, how they generated their customer base, how they measured their programs' or students' success (e.g., improved grades), and how they signalled their effectiveness to parents.

Interviews were analyzed using QSR NUD*IST (for a review see Dohan and Sanchez-Jankowski 1998; see also Huberman and Miles 2002; Saldaña 2009). Each interview was coded four times. We initially used a structured coding method, developing nodes based on our interview schedule (Saldaña 2009). This coding was largely descriptive, and parsed interview data into broad categories without the benefit of interpretation. Second phase coding organized the data into more abstract, theoretically informed categories. To do this, we isolated quotes that captured the interplay between competitive pressures and entrepreneurs' responses. At this stage, we used two simultaneous coding strategies: one based on preestablished hypotheses, and the other based on an open coding scheme that allowed us to inductively add free and tree nodes as they emerged from our data (Saldaña 2009; Strauss and Corbin 1998). Third stage coding identified key statements or actions, and grouped them together into one master tree (Competition) and two key child nodes germane to this paper (Nonstrategic Action and Strategic Action). A fourth and final stage of coding refined our grandchild and great-grandchild nodes (Saldaña 2009; see also Miles and Huberman 1994).

"Competition" broadly captured interviewees' awareness or knowledge about competitive pressures. We then divided our responses into two categories to capture their reactions to the competitive environment, 
Figure 1. Nonstrategic Responses

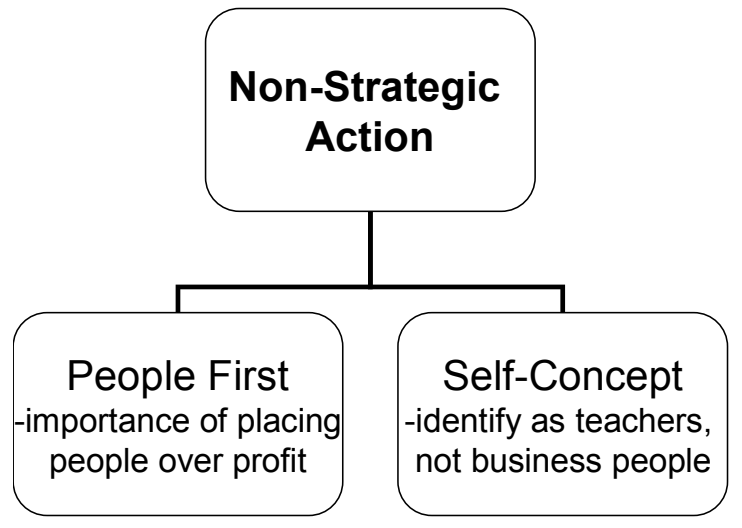

Figure 2. Strategic Responses

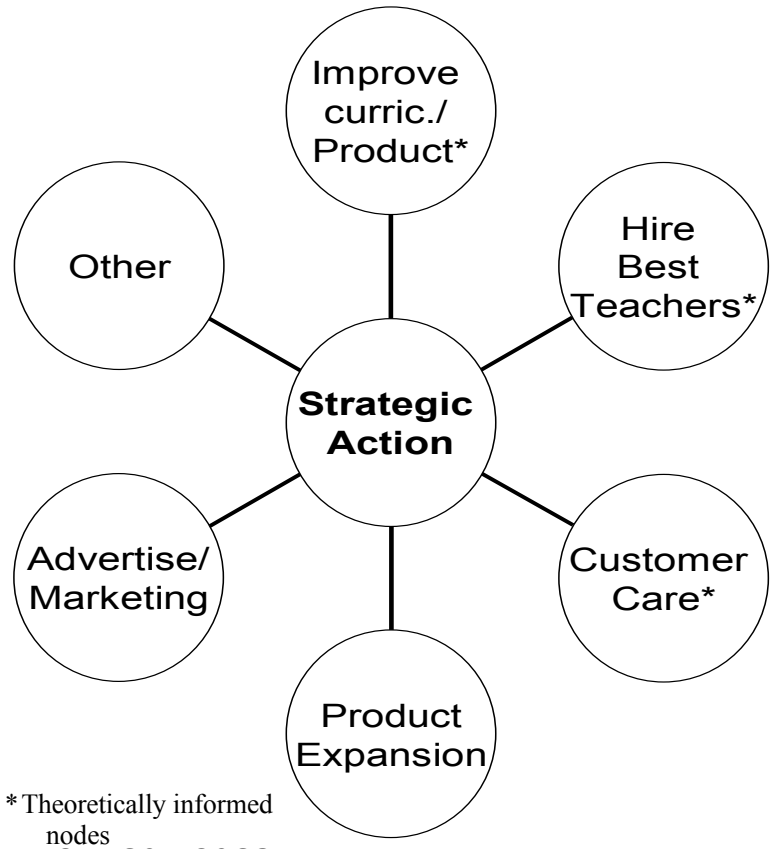

"Nonstrategic Action" and "Strategic Action." Interviewees who did not acknowledge or respond to competitive forces were placed in a Nonstrategic Action category. This node was then subdivided into two grandchild nodes to capture the two main reasons entrepreneurs gave us for ignoring or dismissing the competitive environment: "People First" and "Self Concept." These categories emerged from our interviews. People 
First includes all statements that cite the importance of placing their customers' needs over their own, profits, or the actions of other businesses. Self Concept captures interviewees who claim to not respond to the competitive environment because they see themselves as "teachers" or "educators" rather than "business people."

Interviewees who acknowledge and respond to competition were first placed into a generic Strategic Action category. Interviewees were asked to provide examples and to elaborate on how the competitive environment directly or indirectly influenced decisions regarding their products or services, and hiring practices. Based on the literature and our interviewees' responses, we created five subnodes. Theoretically informed nodes are: 1) Improve Curriculum/Product, 2) Hire Best Teachers and 3) Customer Care. These nodes capture specific actions that should directly improve the quality of the program and services. The remaining two responses to competition include: 4) Product Expansion and 5) Advertise/ Marketing. These nodes emerged spontaneously from our interviewees. The Product Expansion node includes statements about expanding their products or programs in response to competition. Advertise/Marketing refers to interviewees' attempts to combat competition through clever marketing campaigns. We also developed a more general Other category to capture a wide range of responses that emerged from our interviews (Strauss and Corbin 1998).

\section{Findings: Micro-level Responses to the Competitive Environment}

The market hypothesis is unequivocal in its claim that competition encourages a heightened sensitivity to the larger competitive environment, and that this awareness inspires organizations to respond by improving their goods and services. Indeed, many of our private education entrepreneurs described improving their programs or services and hiring high quality teachers. Despite rising costs, for example, the principal of Bathurst High only hires the "cream of the crop," teachers with at least 15 years of experience, while Union Academy hires many teachers with graduate degrees. Several of our interviewees also discussed continually improving the quality of their programs or services and the importance of excellent customer service. Overall, our interviewees emphasized, sometimes quite passionately, the importance of providing a high quality education service and meeting the unique needs of their clientele. While it would be easy to attribute these attitudes and responses to the competitive environment, most of our interviewees were not aware of their com- 
petitors, and consequently were unable to attribute a particular program, hiring, or service improvement to the competitive environment.

As we outline below, our interviewees' responses suggest that they are driven by a highly personal commitment to providing a high quality service. While this orientation certainly yielded competitive advantages for several of our interviewees, it was a latent (not manifest) product of a particular worldview and self-concept. Below we outline our interviewees' awareness of and response to the competitive environment using our two master tree nodes: Nonstrategic Action and Strategic Action.

Figure 3. Education Organizations' Responses to Competition

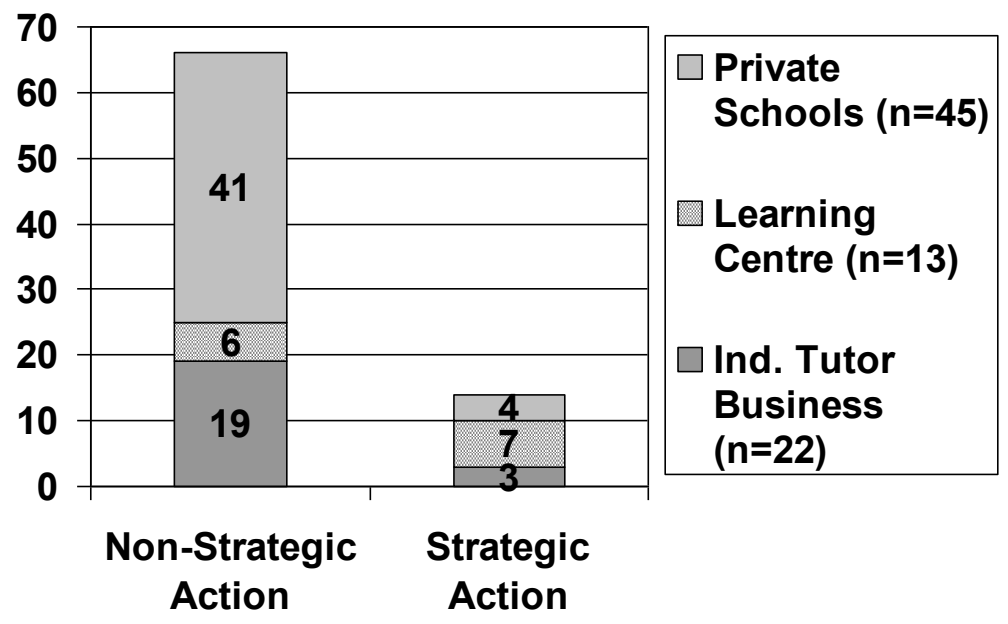

Nonstrategic Action: "Competition? That's a very Strange Question..."

According to the market hypothesis, competitive forces motivate best practices, as organizations jockey for position in a crowded marketplace. In the school choice literature, these responses are typically theorized to translate into deliberate curriculum and program innovations, optimal staffing decisions, and superior customer services. If this hypothesis holds true, logically entrepreneurs must be at least minimally aware of their competitors and should be able to link a particular response to market competition.

During interviews, we probed several times about competitive pressures, asking a variety of questions, rewording previously asked questions, and outlining a number of scenarios that could potentially compromise their business (e.g., a competitor slashing prices). We asked our interviewees about their competition, their competitors' services and 
teaching methods, and their competitors' customer service reputations. We also asked our interviewees to discuss how or whether the presence of their competitors informed their decisions, even minimally. Interestingly, we found that most of our interviewees had little or no information about their competitors, nor their competitors' programs or services. Overall, we found that while many of our interviewees discussed curriculum, staffing, and customer service improvements, they did not connect these improvements to the competitive environment.

In fact, several of our entrepreneurs looked confused when asked questions about the competitive environment (such as how they monitor their competitors' programs or whether they are concerned about a competitor who recently opened up across the street). The majority of our interviewees admitted knowing very little about their competitors, even those within walking distance. Our interviewees were generally unable to identify the programs or services, pricing structures, staffing, or even the general reputations of nearby or comparable businesses. The response of the founder of Castle Frank High was fairly typical of our interviewees: "I don't know what other private schools do. I've never looked at it." The owner of Alexander Independent Tutoring was clearly embarrassed by her lack of information about her competitors and told us " $[y]$ ou know I don't ever think about the competition. I really don't keep on top of it, though I guess I should...." Similarly, another principal (Aldershot High) told us, "This is what we want to do and I really don't care [what other businesses do]. They can do what they want."

Rather than competition, many of our interviewees provided two interconnected rationales for improving the quality of their programs or services that we refer to as "nonstrategic" in the market hypothesis sense of the term: 1) People First; and 2) Self-Concept. First, several interviewees passionately discussed the importance of putting people first. Indeed, without prompting, many of these interviewees believed that a focus on neighbouring businesses eroded, rather than contributed to, the quality of their educational programs. When asked how she monitors her competitors, the owner of an independent tutoring business (Fairview Independent) responded:

That's a very strange question. But no, we just do our thing.... My world is pretty much enclosed here. My concern is here, I couldn't be bothered with that. It would be a total waste of my time. I couldn't even tell you the names of the other businesses! It's not my focus. My focus is on the students who come through our doors. That's my focus. So no, I don't worry about my competitors.... 
Several other private school interviewees also exhibited a lack of concern about potential competitors. These interviewees believe that owners who focus on the competition are profit, rather than people, driven. As the owner of Bay High explained:

It is a business at the same time, but it's not like we're out to rule the tutoring world or the private educational world. We just want to focus on what we do, and do it to the best of our abilities.

The People First commitment sometimes meant turning students away, typically to another school or program that they felt could better meet a child's needs. ${ }^{3}$ As the owner of a third sector school (Wellesley Academy) explained, “[w]e are talking about children's lives here and education without integrity is going nowhere. You have to be able to say, 'no I can't meet this child's needs'."

The People First rationale was directly related to how entrepreneurs made sense of their role in the wider environment of schooling, which we refer to as "Self-Concept." The competitive environment is irrelevant because most of these interviewees see themselves as educators, not business people. ${ }^{4}$ The owner of Castle Frank High, a private school, told us, "[w]e never thought of it as a business," and admits waiving fees for several scholarship students. Similarly, the owner of Casa Blanca Independent Tutoring explained:

Oh no, I never care [about the competition]! I told you, I'm not a business woman. I just do whatever I think is right ... I've heard from my students and parents that there are many schools around here.... But that's it. I never worry about the other businesses.

Several learning centre franchisees also expressed this sentiment, despite having access to an incredible array of industry research that would

3. Turning students away is not a function of "creaming the best students." In fact, third sector schools generally do not track or advertise their academic standing based on standardized test scores, graduation rates, or ability to place students in desirable postsecondary institutions (Davies and Quirke 2007). Instead, many either emphasized a caring, nurturing atmosphere over rigorous academics, or did not tailor their offerings in order to recruit high-performing students (Davies and Quirke 2007).

4. Of the third sector school principals, half were not certified as teachers, and had come to run a private school through a diverse array of backgrounds. Five had previously worked in business, while others hailed from a diverse number of backgrounds: nursing, computer training, a nonprofit organization, and working with special needs children. Other uncertified principals had some education-related experience: tutors, a daycare supervisor, and one taught at the university level outside of Canada. Of the other half of principals, who were certified teachers, most had taught in public schools (see Quirke, 2009). While several of the franchisers have business backgrounds or experience in business related fields, many of the independent business owners and franchisees have backgrounds in education, psychology, or early childhood development. 
provide them with cutting edge information about their competitors. As one of our franchisees (Dewitt Learning Centre) explained, "[i]t's more from the heart":

I'm not really business minded. It's more from the heart. The way I feel about the children who come here, they are my neighbour's children and my children's peers.... We're not just going to take them but we're going to give a good program because we love you. I have a responsibility. I have an attachment to the people here.... I see it as my community, more than as a business.

As the independent owner (Casa Blanca Independent Tutoring) quoted above told us, putting students' needs above her own meant she could "sleep at night." She explained that she decided to base the studentteacher ratio on her students' needs, rather than on the bottom line:

I told you I'm not a business woman, I enjoy teaching. My previous owner, he had seven or eight students for every teacher... When I took over, I decided to have mainly one-on-one ... it's not good for business.

But I feel very, very comfortable with that.

In summary, most of our interviewees had limited knowledge about their competition, and did not actively gather information about their competitors. Moreover, most interviewees failed to cite the competitive environment as a source of positive change. Thus while almost all businesses discussed improving their product or service delivery, we found little evidence to suggest that competition drives these practices. These interviewees attributed their lack of knowledge about the competitive environment to their commitment to their customers and their perception of their role in the wider environment of schooling. Certainly, a strong customer service orientation (People First) or caring and charismatic leadership (Self Concept) may yield impressive competitive advantages. Our argument is that for these entrepreneurs, competition does not drive these responses, but may be an unintended benefit of their commitment to students or self-concept as educators.

\section{Strategic Action: Direct Responses to Competition}

A minority of our interviewees were more aware of the competitive environment and could describe how market forces inspired a particular response or change (two independents, franchisers, a former franchise representative, and four third sector principals). These owners discussed the importance of continual product development, the challenge of finding good teachers, and why good customer service matters. Again, none 
of these interviewees connected improving the content or delivery of their services to the competitive environment. Instead, these interviewees mitigated competitive forces by expanding their product line or improving their advertising.

In terms of product expansion, some franchisers discussed adding a day-time program to reduce overhead costs and improve the overall profitability of the centre. Since most tutoring occurs in the evening, offering a preschool or adult retraining program during the daytime offset expenditures such as rent, office supplies, and educational materials. Preschool programs were also seen to attract future tutoring or private school clients. As one franchiser (Dewitt Learning Centre) explained:

The adult business was there more to, in the beginning it was more of a capacity issue. There was nothing going on in our centres during the day that brought value.... The benefit of having the preschool is that those are potential customers down the road for you, where your margins are a bit higher ... and more to try to offset some of our costs during the day.

Similarly, the former Canadian representative and current franchisee of a major learning centre (International Learning Centre) also explained how the company strategically maps out the trajectory of a potential client. The franchise's research department determined that most clients go through a series of stages when purchasing educational services. This franchise responded by adding several layers of new programs and services to tap into each stage of educational purchasing behaviour, with the goal of generating revenue along a client's pathway to the learning centre. At the time of the interview, the franchise had just purchased a very well-known company that makes educationally focused games, books and other toys. As she explained:

There's this whole ladder that a person will go through before they actually make it into a learning centre. First, they'll try going to the library, then they'll go to somewhere like Chapters ... so they come up this ladder before they come to see us ... they're [franchiser] trying to segment the market and get people at every stage.

A few interviewees also discussed developing a parallel service in response to the competitive environment. Adding online courses, a summer camp, or high school math tutorial were just some of the ways businesses broadened their customer base. As the franchiser from Dewitt Learning Centre explained, developing a lower priced tutoring line allowed them to tap into another segment of the tutoring marketplace:

When we started in business, we were competing against [competitor $\mathrm{A}]$ and [competitor B]. What we found is that all of us were competing 
against that high end consumer who was willing to spend $\$ 300$ to $\$ 350$ a month. But down on the other end was [competitor C] which is at $\$ 70$ a month and really absolutely no competition what so ever. Over time we realized that [lower level] might be an area we might want to go after.

In addition to expanding their product line, these interviewees also discussed sharpening their advertising and marketing in response to the competitive environment. These interviewees discussed spending a great deal of time selecting which newspapers to advertise in, and even the size and location of particular advertisement in the phone book or newspaper. As the owner of a multifaceted tutoring business (Flamborough Independent) explained, to accelerate growth he needs to "push at it":

Right now I'm just mostly advertising to the Chinese market. Because that's for the dollars, you get the best return. You go in the sort of Canadian community papers, it's lots of money, lots of time but you really have to sort of push at it, and keep it going. But if you have things welldefined, then it'll be able to accelerate your growth.

Similarly the owner of a tutoring business and private school (Don Valley Tutoring) explained why he decided to pay for a larger ad in the phonebook, despite the added cost. He argued that:

[Y] es, it was definitely worth the money. All the new students were coming from there.... We used to get so many more calls ... when we went to the larger ad.

These interviewees also cited responding to competition through various rebranding efforts. The above former representative (Dewitt Learning Centre) explained how the company originally promoted basic reading and math skills. Focus groups conducted by their marketing division, however, revealed that themes of self-esteem building and children's happiness resonated more strongly with parents. The company altered their advertising to reflect this research, and sales boomed.

It is perhaps not surprising that most of the "strategic" actors in our sample were franchise owners. These interviewees are responsible for the overall management of the franchise, the development of the curriculum, and branding and marketing of the franchise. They also have access to an array of industry information, and use this information to select new locations and develop new product lines. Their responsibility is neither the day-to-day functioning of the centres nor interacting with their clients, but rather managing the overarching vision and stability of the company. In contrast, most frontline actors in our sample - franchisees, managers, and principals — whose personal economic survival 
often depends on their ability to generate a stable revenue stream were decidedly unaware of and uninspired by the potentially harsh realities of the competitive environment.

\section{How Micro-Level Understandings Shape Responses to Macro- LeVEL ENVIRonMents}

The market hypothesis has generated a cottage industry of articles and books (e.g., Chubb and Moe 1990; Friedman 1962; Henig 1999; Hirsch 1995; Hoxby 2000; Maranto et al. 2001; see also Peterson and Campbell 2001; Ouchi 2003; Wilson 2006). While inspiring us to think about how alternative bottom-up governance structures may inspire positive change, the empirical underpinnings of this perspective have not been given adequate attention at the micro level. We extend these examinations by bringing the frontline actors of the private education marketplace into the foreground and consider how they respond to macro-level competitive environments.

Through this lens, private educators' actions can no longer be attributed to some mythical "invisible hand" or "whip." In fact, while most variants of the market hypothesis privilege the environment of organizations, our interviewees (some more forcefully than others) ignored and at times rejected competitive pressures emanating from the environment. We found that market forces were just one of the many resources interviewees used to guide their decision making. Private educators responded to competition directly, symbolically, or not at all, based on their interpretations about its meaning and its congruence with their worldview as business persons or educators (see Berger and Luckmann 1966; Swidler 1986; Weick 1995). Thus, while interviewees acknowledged that in theory they "should" pay more attention to their competitors most of them had ultimately decided that it was a "waste of time" because it not only would take precious time away from their clients, but they were "educators." For many of our interviewees, time spent crafting strategic responses to a competitor meant time away from their students. This understanding of their role informed their orientation (or lack of orientation) toward market pressures. Consequently, the vast majority of our interviewees did not connect market forces to consequent goods and service improvements. Instead, we found that Improving Curriculum/ Product, Hiring the Best Teachers, and Customer Care were cited more often by our nonstrategic interviewees, and connected not to the competitive environment, but rather to their personal commitment to putting "People First" and "Self-concept" as educators. 


\section{Conclusion}

In this paper we elaborate on a growing body of literature on schooling and market environments. While this literature is useful in determining inputs (e.g., student demand) and outcomes (e.g., comparing private and public school student test scores), we hope to add an important window into the world of private education and responses to market environments more generally.

Empirically, analyzing the micro-foundations of private education allows us examine how decisions are made and to ask why particular actions are taken over others. We were able to give voice to private educators by allowing them to share with us how they understood pressures outside of their organization, and what ultimately guides their decision making. Understanding the micro-foundations of private education organizations requires analyzing the "cognitive complexities" (Jennings and Greenwood 2003) that ultimately guide behaviour and recognizes the "varied ways that institutionalized practices operate at the micro-level" (Powell and Colyvas 2008:12). This line of inquiry recognizes that while organizations may operate under a similar set of environmental pressures (e.g., "competitive environment"), responses are always nested in actors' worldviews. Such cognitive frameworks guide micro-level responses, and may account for the multiple ways actors come to interpret and respond to pressures emanating from the environment. Thus while prevailing institutionalized scripts may appear objective, they are always filtered through the unique repertoires and schemas of individual organizations and their members (Berger and Luckmann 1966).

Theoretically, this vantage point allows us to bring the macro-micro link into sharp relief. For our interviewees, "competition" was not a theoretical or political ideal, but rather a dimension of doing business that many of them did not believe was consequential to their everyday operations or to their survival. Among our interviewees, "best practices" were not the result of market rationalization processes, but the symbol of a personal and moral commitment to teaching and learning. These findings suggest the need for a more careful and systematic examination of the mechanisms (market or other) that may inspire efficiency — whether efficiency denotes optimal decision-making, production, hiring, or service delivery.

Future qualitative research may offer more insight into why quantitative research has yet to demonstrate clear and consistent evidence on the benefits of market environments. Some quantitative research has found that while parents and students generally report higher levels of satisfaction with choice options, academic gains through competitive processes 
tend to be "substantively modest" (Belfield and Levin 2002:297; see also Goldhaber 1999). A systematic review of the effects of market competition on schooling outcomes by Belfield and Levin (2002:297), for example, found that "Between one-third and two-thirds of the estimates lack statistical significance." However most studies tend to focus on a particular geographically bounded charter school or voucher experiment. These examples have also yielded less than impressive results. A UCLA study, for example, of 39 representative charter schools in 10 districts found that while these schools were financially accountable, they failed to uphold academic standards and often required outside interventions (UCLA Charter School Research Associates, 1998).

In a (rare) Canadian study, O'Reilly and Bosetti (2000:31) did find evidence of significant innovative approaches (e.g., Suzuki method of teaching) and that charter school students are "generally achieving at least as well as students in other jurisdictions." Not surprisingly, the authors note that the educational achievement gaps can be partly explained by students targeted by charter schools (e.g., gifted students, low achieving students), and also by the high levels of education and income of most charter school families. Interestingly, rather than academic achievement, most teachers believed that their school's most significant accomplishment was children's socioemotional development. This finding mirrors similar Canadian research on third sector private schools in Ontario (Davies and Quirke, 2005). This research finds that nonelite, nonreligious private schools tend to focus on a particular pedagogical approach (e.g., museum based education). These schools do not advertise, nor focus on, academic indicators of excellence (e.g., EQAO test scores, entrance to university), but instead purport to cater to children's individual interests and personal development (Quirke 2009). Choice and the freedom to select schools that match parents' teaching or parenting philosophy are what appear to increase satisfaction, regardless whether this choice generates tangible academic outcomes or creative teaching and learning practices.

These studies provide little support that market competition unleashes innovative practices. Lubienski's (2003) comprehensive examination of the influence of competition and choice on charter schools, for example, found that overall most classrooms and pedagogical strategies are similar to regular public schools. In fact, Lubienski (2003) argues that the very market forces that attempt to unleash creativity are the same pressures that demand outcome-based performance standards. This latter pressure ultimately undermines innovation by encouraging curricular conformity and instructional standardization. In another paper he notes that while several studies illustrate an unexpected lack of innovation to 
core practices, researchers find innovation in other, noneducational, aspects of charter schools such as marketing (Lubienski 2005; see also Goldhaber 1999). Our data support this finding.

This area of research faces numerous obstacles. While private education has grown in Ontario, there are few credible sources of data to evaluate their quality and creativity or map their trajectories. Schools of choice are funded by the state in Alberta (see Bosetti 2000 and Taylor and Mackay 2008), and private schools in Québec are subsidized by the state (Desjardins 2006). However, as partially or fully state funded options, they are quasi-market schooling organizations at best. These conditions in Canada and elsewhere (e.g., United States) seriously compromise researchers' ability to evaluate how market competition influences educational achievement or teaching and learning practices.

One area of further research is the question of whether actors in other "helping fields" in the private sector would act according to the market hypothesis. We speculate that the small organizational size of the educational businesses we surveyed maximized organizational actors' latitude and ability to make nonstrategic choices. As Brint (1994) argues, professions should not be seen in isolation from the sphere (i.e., business versus human services) in which occupations operate; we argue professional versus nonprofessional occupational groups might bring various occupational status and sensibilities that to their work. We argue that professional actors (i.e., teachers, speech language pathologists, nurses, dentists) doing "helping" work in for-profit settings need to manage the demands of the dominant ethos of both the for-profit business and "human services" sphere in their treatment of personal problems (see Brint 1994). However, it is unclear whether or how uncertified staff members who do human services work in the for-profit sector would adopt or enact market theory predictions. This is a fertile area for future research.

\section{REFERENCES}

Aurini, Janice. 2004. Educational entrepreneurialism in the private tutoring industry: Balancing profitability with the humanistic face of schooling. Canadian Review of Sociology and Anthropology 41(4):475-491.

Aurini, Janice and Scott Davies. 2004. The transformation of private tutoring: Education in a franchise form. Canadian Journal of Sociology 29(3):418-438.

Belfield, Clive R. and Henry M. Levin. 2009. Market reforms in education. Pp. 513-527 in Gary Sykes, Barbara Schneider, and David N. Plank, eds., Handbook of Education Policy Research. New York: Routledge. 
2005. Vouchers and public policy: When ideology trumps evidence. American Research Journal 111(4):548-567.

2002. The effects of competition between schools on educational outcomes: A review for the United States. Review of Educational Research 27(2):279-341.

Berger, Peter L. and Thomas Luckmann. 1966. The Social Construction of Reality. Garden City, NJ: Doubleday.

Bosetti, Lynn. 2000. Alberta charter schools: Paradox and promises. Alberta Journal of Educational Research 46(2):179-190. 1998. The dark promise of charter schools. Policy Options (July-August):63-67.

Bosetti, Lynn and Michael C. Pyryt. 2007. Parental motivation in school choice: Seeking the competitive edge. Journal of School Choice 1(4):89-108.

Brint, Steven. 1994. In an Age of Experts: The Changing Role of Professionals in Politics and Public Life. Princeton, NJ: Princeton University Press.

C.D. Howe Institute. Accessed July 30, 2010 at: http://www.cdhowe.org/index. $\underline{\mathrm{cfm}}$

Chubb, John E. and Terry M. Moe. 1990. Politics, Markets and American Schools. Washington: Brookings Institute.

1988. Politics, markets and the organization of schools. The American Political Science Review 82(4):1065-1087.

Davies, Scott and Linda Quirke. 2007. The impact of sector on school organizations: Institutional and market logics. Sociology of Education 80(1):6689.

2006. Innovation in educational markets: An organizational analysis of third sector private schools in Toronto. In Maureen T. Hallinan, ed., School Sector and Student Outcomes. Notre Dame: University of Notre Dame Press.

2005. Providing for the priceless student: Ideologies of choice in an emerging educational market. American Journal of Education 111(4):523-547.

Davies, Scott, Linda Quirke, and Janice Aurini. 2006. The new institutionalism goes to the market: The challenge of rapid growth in private K-12 education. In Heinz-Deiter Meyer and Brian Rowan, eds., The New Institutionalism in Education. Albany, NY: SUNY Press.

Desjardins, Pierre-David. 2006. Institutionnalisation de la régulation marchande en éducation: étude des logiques de décisions et d'action dans les établissements secondaires du Québec. In Revue les recherches en espaces francophones, enseignement, éducation, formation, ed. G. Boutin and T. Montoya, No. 6, 91-103. Québec: Presses de l'Université de Québec.

Dohan, Daniel and Martin Sandez-Jankowski. 1998. Using computers to analyze ethnographic field data: Theoretical and practical considerations. Annual Review of Sociology 24:477-498. 
Dooley, Martin David and Abigail Payne. 2007. School competition and efficiency with publicly funded Catholic schools. Paper presented at the annual meetings of the Canadian Labour Market and Skills Research Network, Toronto.

Friedman, Milton. 1962. Capitalism and Freedom. Chicago: University of Chicago Press.

Goldhaber, Dan. 1999. School choice: an examination of the empirical evidence on achievement, parental decision-making, and equity. Educational Researcher 28(9): 16-25.

Henig, Jeffrey. 1999. School choice outcomes. Pp. 68-108 in Stephen D. Sugarman and Frank R. Kemerer, eds., School Choice and Social Controversy: Politics, Policy and Law. Washington: Brookings Institution Press.

Hirsch, Donald. 1995. School choice and the search for an educational market. International Review of Education 41(3-4):239-257.

Holmes, Mark. 2008. An update on school choice in Canada. Journal of School Choice 2(2):199-205.

Hoxby, Caroline. 2000. Does competition among public schools benefit students and taxpayers? The American Economic Review 90(5):1209-1238.

Huberman, Michael A. and Matthew B. Miles. 2002. The Qualitative Researcher's Companion. Thousand Oaks, CA: Sage Publications.

Jennings, P. Devereaux, and Royston Greenwood. 2003. Constructing the iron cage: Institutional theory and enactment. Pp. 195-207 in Robert Westwood and Stewart R. Clegg, eds., Debating Organization: PointCounterpoint in Organization Studies. Malden, MA: Blackwell.

Lieberman, Myron. 1993. Public Education: An Autopsy. Boston, MA: Harvard University Press.

Lubienski, Chris. 2005. Public schools in marketized environments: Shifting incentives and unintended consequences of competition-based educational reforms. American Journal of Education 111(4):464-486.

2003. Innovation in education markets: Theory and evidence on the impact of competition and choice in charter schools. American Educational Research Journal 40(2):394-443.

Maranto, Robert, Scott Milliman, Frederick Hess and April Gresham, eds. 2001. School Choice in the Real World: Lessons from Arizona Charter Schools. Boulder, CO: Westview Press.

Megginson, William L. and Jeffry M. Netter. 2001. From state to market: A survey of empirical studies on privatization. Journal of Economic Literature 39:321-389.

Merrifield, John. 2008. Dismal Science: The Shortcomings of U.S. School Choice Research and How to Address Them. Policy Analysis, No.616.CATO Institute, pp. 1-20. 
Meyer, John and Brian Rowan. 1978. The structure of educational organizations. Pp. 78-109 in Marshall Meyer, ed., Environments and Organization. San Francisco: Jossey Bass.

Miles, Matthew B. and Michael A. Huberman. 1994. Qualitative Data Analysis. Second edition. Thousand Oaks, CA: Sage Publications.

National Governors' Association. 1991. Time for Results: The Governors' 1991 Report on Education. Washington: National Governors' Association Publications Office.

Ontario Ministry of Education. 2011. Accessed at http://www.edu.gov.on.ca/eng/ elementary.html

O'Reilly, Robert R. and Lynn Bosetti. 2000. Charter schools: The search for community. Peabody Journal of Education 75(4):19-36.

Ouchi, William G. 2003. Making Schools Work: A Revolutionary Plan to Get Your Children the Education They Need. New York: Simon and Schuster.

Peterson, Paul E. and David E. Campbell, eds. 2001. Charters, Vouchers, and Public Education. Washington: Brookings Institution Press.

Powell, Walter W. and Jeannette A. Colyvas. 2008. Microfoundations of institutional theory. Pp. 276-298 in Royston Greenwood, Christine Oliver, Kerstin Sahlin, and Roy Suddaby, eds., Handbook of Organizational Institutionalism. Thousand Oaks, CA: Sage Publications.

Quirke, Linda. 2009. Legitimacy through alternate means: Schools without professionals in the private sector. British Journal of Sociology of Education 30(5):621-634.

Robson, William and Claudia Hepburn. 2010. Learning from success: What Americans can learn from school choice in Canada. School Choice Issues in Depth (1:2), a joint publication of the Milton and Rose D. Friedman Foundation and the Fraser Institute. Accessed on July 30, 2010 at: http:// www.fraseramerica.org/Commerce.Web/product files/LearningFromSuccess.pdf.

Saldaña, Johnny. 2009. The Coding Manual for Qualitative Researchers. Thousand Oaks, CA: Sage Publications.

Scott's Directories. 2006-2008. Ontario Business Volume. International Press Publication, Inc.

Strauss, Anselm and Juliet Corbin. 1998. Basics of Qualitative Research: Techniques and Procedures for Developing Grounded Theory. Second edition. Thousand Oaks, CA: Sage Publications.

Swidler, Ann. 1986. Culture in action: Symbols and strategies. American Sociological Review 51(2):273-286.

Taylor, Alison and Jesse Mackay. 2008. Three decades of choice in Edmonton schools. Journal of Educational Policy 23(5):549-566. 
UCLA Charter School Research Associates. 1998. Beyond the Myth of Charter School Reform. Los Angeles: UCLA Charter School Research Associates.

Weick, Karl E. 1976. Education organizations as loosely coupled systems. Administrative Science Quarterly 21:1-19. 1995. Sensemaking in Organizations. Thousand Oaks, CA: Sage Publications, Inc.

Wilson, Steven F. 2006. Learning on the Job: When Business Takes on Public Schools. Cambridge, MA: Harvard University Press.

Witte, John F. 2000. The Market Approach to Education: An Analysis of America's First Voucher Program. Princeton, NJ: Princeton University Press.

Zimmer, Ron, Laura Hamilton, and Rachel Christina. 2010. After-school tutoring in the context of No Child Left Behind: Effectiveness of two programs in the Pittsburgh public schools. Economics of Education Review 29(1):18-28.

Janice Aurini is an Assistant Professor, University of Waterloo, Department of Sociology and Legal Studies. Her current research includes a qualitative examination of upper middle class parenting in Canada and the United States and a multimethod examination of summer setback.

Linda Quirke is assistant professor in the Department of Sociology at Wilfrid Laurier University in Waterloo, Ontario, Canada. Her research interests include the sociology of organizations, schooling, childrearing and children`s physical activity. 